\title{
Autosomal Recessive Osteogenesis Imperfecta: A Puzzle for Bone Formation, Structure and Function
}

\author{
Sergei P. Boudko • Elena N. Pokidysheva • \\ Hans Peter Bächinger
}

Published online: 27 September 2013

(C) Springer Science + Business Media New York 2013

\begin{abstract}
Bone is a composite material that resembles reinforced concrete. The collagen matrix plays the role of reinforcement, whereas hydroxyapatite crystals are cementing material. Collagen fibers are responsible for the tensile strength of bones and prevent fractures from extending; the mineral phase is able to withstand compaction loads. A right balance of these two parts synergistically provides the required stiffness for bone. Collagen abnormalities, such as reduced amount, disturbed composition, defects in structure and/or supramolecular organization as well as insufficient or defective mineralization, lead to osteogenesis imperfecta (OI), also known as brittle bone disease. Until recently, mutations in the type I collagen genes COL1Al and COL1A2 were the only known causes of the disease, which cover about $90 \%$ of diagnosed OI. Within the last decade, we have witnessed a burst in the identification of new OI mutations in other genes. Here we summarize our knowledge of these mutations and their impact on bone quality.
\end{abstract}

S. P. Boudko · E. N. Pokidysheva · H. P. Bächinger $(\bowtie)$

The Research Department, Shriners Hospital for Children, 3101

SW Sam Jackson Park Road, Portland, OR 97239, USA

e-mail: hpb@shcc.org

S. P. Boudko

e-mail: spb@shcc.org

E. N. Pokidysheva

e-mail: enp@shcc.org

H. P. Bächinger

The Department of Biochemistry and Molecular Biology, Oregon Health and Science University, Portland, OR 97239, USA
Keywords Osteogenesis imperfecta $\cdot$ Autosomal recessive - Protein folding - Posttranslational modification . Hydroxylase · Hydroxyproline - Hydroxylysine . Glycosylation · Chaperone · Cross-linking

\section{Introduction}

Osteogenesis imperfecta (OI), a genetic disease, is primarily characterized by increased bone fragility and reduced bone mass [1]. Its overall frequency is about $10^{-4}$. Bone fragility has led to the trivial name of 'brittle bone disease.' The most severe OI forms correlate with the strongest defects in collagen fibers. As collagen is an important component in other connective tissues, patients affected by OI generally exhibit an additional set of symptoms, including short stature, dentinogenesis imperfecta, loose joints, skin hyperlaxity, hearing loss, blue sclera, and neurological and pulmonary complications. Collagen matrix abnormalities also affect the mineral phase of bone. Bones from OI patients show a lower average bone mineral density and break more easily when deformed; in addition, fatigue damage accumulates much faster on repetitive loading of OI bones [2]. The material properties of the matrix are an important aspect in studying the mechanisms of OI.

In most OI studies, collagen production is examined in skin fibroblasts. Much less is known about the effects of mutations on osteoblasts, the primary sources of collagen in bone. Osteoblasts may differ with regard to post-translational modifications of collagen as well as in the propensity to incorporate collagen molecules into the extracellular matrix. Indeed, a recent study on 3-hydroxyproline sites in type I collagen from different tissues of the wild-type and LEPRE1-deficient mice showed not only the 
variability in the post-translational modification between skin, tendon and bone, but also demonstrated a change in the expression profile of other 3-hydroxylases [3•]. Osteoblasts harboring an OI mutation may also have an abnormal expression pattern of other matrix proteins, such as proteoyglycans, hyaluronan, asporin, decorin, fibronectin, thrombospondin, osteocalcin, SPARC and others.

Certain types of mutations leading to OI are associated with the induction of an endoplasmic reticulum stressspecific unfolded protein response involving upregulation of BiP, Hsp47 and Gadd153 with caspase-12 and -3 activation and apoptosis of osteoblasts both in vitro and in vivo [4]. Most of the newly identified OI mutations remain unexplored in terms of induction of the ER unfolded protein response.

Recently new OI mutations were identified in non-collagenous genes, i.e., PLOD2, CRTAP, LEPRE1, PPIB, BMP1, SERPINH1, SERPINF1, FKBP10, TMEM $38 B$, IFITM 5, SMPD3, SP7 and WNT1, and the list is likely to be increased. All of these mutations are autosomal recessive, with the exception of an 'activating' dominant mutation in IFITM5 [5•, 6•]. There are also recessive and dominant mutations found in $W N T 1[7,8 \bullet \bullet, 9 \bullet, 10 \bullet, 11]$. Here we review autosomal recessive OI mutations in genes not coding for collagen type I chains.

\section{P3H1•CRTAP•CypB Complex}

CRTAP was the first non-collagenous gene where human mutations were found to cause OI [12]. The primary indication of the existence of a complex of P3H1 •CRTAP•CypB was previously reported by Vranka et al. [13] and further characterized in the CRTAP OI study [12]. Reports that alterations in LEPRE1 (gene for $\mathrm{P} 3 \mathrm{H} 1$ ) and PPIB (gene for CypB) cause very similar phenotypes as well as more cases of CRTAP mutations followed quickly [14•, 15-20]. Today, multiple cases of recessive OI due to mutations in components of the complex have already been described, and clinical cases and mouse models involving CRTAP, P3H1 and CypB keep accumulating (https://oi. gene.le.ac.uk/home.php?action=switch_db).

The molecular mechanism leading to OI in these cases remains speculative. In normal type I collagen, there is a single site, Pro986 in the $\alpha 1$ chain, which is fully 3-hydroxylated. Most mutations in CRTAP, LEPRE1 or $P P I B$ abolish this modification [14•, 15-17, 20, 21]. There are, however, a few exceptions $[22,23 \cdot]$ in which residual activity of $\mathrm{P} 3 \mathrm{H} 1$ probably remains.

Mutations in all three genes usually result in overmodification (excess of lysyl hydroxylation and glycosylation) of collagen pro- $\alpha$ chains in the ER, presumably due to their delayed assembly into triple helices $[12,14 \bullet, 21,23 \bullet]$. This phenomenon is also observed in the dominant OI forms with collagen mutations $[24,25]$. A role of the $\mathrm{P} 3 \mathrm{H} 1 \cdot \mathrm{CRTAP} \cdot \mathrm{CypB}$ complex in accelerating collagen folding is suggested, and an in vitro study has established that it is a potent molecular chaperone [26]. It has to be noted that CypB exhibits diverse functions and is involved in other interactions besides being a part of the $\mathrm{P} 3 \mathrm{H} 1 \cdot \mathrm{CRTAP} \cdot \mathrm{CypB}$ complex. It was recently demonstrated that an $\mathrm{N}$-terminal missense mutation in $P P I B$ probably alters the activity of the lysyl hydroxylase 1 (LH1) without affecting the catalytic activity of CypB, which results in near normal collagen modifications regardless of the delayed folding rate [27•] (Table 1).

The absence of the 3-hydroxyl group at Pro986 or delayed folding leading to the excessive sugar modifications in type I collagen are two possible causes that lead to OI pathologies. Which one is the primary factor remains to be explored. The missing 3-hydroxyl group at Pro986 could also affect interactions of collagen with other matrix or signaling molecules, whereas extra sugars might adversely affect fibril assembly and the mechanical properties of bones as well as aberrantly influence fibril interactions in the bone milieu. It cannot be excluded that both factors contribute cooperatively in the disease. A more elaborate discussion of OI causative mutations in the $\mathrm{P} 3 \mathrm{H} 1{ }^{\circ} \mathrm{CRTAP} \cdot \mathrm{CypB}$ complex components can be found in a recent publication $[28 \cdot]$.

\section{HSP47 (Serpin H1)}

HSP47, encoded by gene SERPINH1, is a collagen-binding protein and a collagen-specific chaperone in the ER. A recessive mutation in Serpinhl leading to an OI phenotype was originally identified in Dachshunds [29], and recently a human mutation in SERPINH1 and its effect on type I procollagen production were reported [30•]. A knockout of Serpinhl in mice leads to embryonic lethality and has pleiotropic effects on collagen-containing tissues [31]. The mature form of type I collagen was significantly reduced in embryonic tissues. Type I procollagen secreted by a fibroblast cell line was protease sensitive at $37{ }^{\circ} \mathrm{C}$ in contrast to the control. Type I procollagen molecules formed aggregates in the ER and secretion was delayed. Cleavage of the proa1(I) N-propeptide was also deficient in Serpinh1-/- fibroblasts.

Human autosomal recessive missense mutation (p.Leu78Pro) in SERPINH1 results in degradation of HSP47 via the proteasome [30॰]. Mutations of SERPINHI do not result in overmodified collagen chains and do not affect Pro986 3-hydroxylation, indicating that the protein interacts with type I procollagen at later stages of biosynthesis [30•]. In addition, secreted type I procollagen trimers have increased protease sensitivity. Although HSP47 can interact with individual chains, it appears that the preferred 
Table 1 Autosomal recessive OI genes

\begin{tabular}{|c|c|c|c|c|c|c|}
\hline Gene & Protein & Overmodification & Secretion & Thermal stability & Other defects & References \\
\hline LEPRE 1 & P3H1 & Yes & Delayed in ER & Higher & Lack of 3-hydroxylation & {$[14 \bullet, 15,18,19,66-68]$} \\
\hline CRTAP & CRTAP & Yes & Delayed in ER & Higher & Lack of 3-hydroxylation & {$[12,15,16,18,20,69]$} \\
\hline$P P I B$ & СурВ & Yes/no & Delayed/normal & Higher & Lack of 3-hydroxylation & {$[17,21,22,70-72]$} \\
\hline FKBP10 & FKBP65 & No & Delayed & Unknown & Telopeptide cross-linking & {$[37 \bullet, 39,40,41 \bullet, 73-76]$} \\
\hline PLOD2 & LH2 & No & Normal & Unknown & Telopetide cross-linking & {$[77,78]$} \\
\hline SERPINHI & HSP47 & Yes/no & $\begin{array}{l}\text { Delayed in ER/ } \\
\text { delayed in Golgi }\end{array}$ & Higher/lower & $\begin{array}{l}\text { Protease degradation of } \\
\text { collagen }\end{array}$ & {$\left[29,30^{\bullet}\right]$} \\
\hline SERPINF1 & PEDF & No & Normal & Normal & $\begin{array}{l}\text { Reduced mineralization; } \\
\text { excessive bone } \\
\text { resorption? }\end{array}$ & {$\left[45^{\bullet}, 46^{\bullet}, 47,48,50^{\bullet}\right]$} \\
\hline$B M P 1$ & BMP1 & No? & No? & No? & C-propeptide cleavage & {$[42,79]$} \\
\hline TMEMЗ3В & TRICB & Unknown & Unknown & Unknown & Mineralization? & {$[56,57]$} \\
\hline$S P 7$ & Osterix & Unknown & Unknown & Unknown & $\begin{array}{l}\text { Reduced collagen } \\
\text { transcription? }\end{array}$ & {$[63,64]$} \\
\hline WNT1 & Wnt1 & Unknown & Unknown & Unknown & Unknown & {$\left[7,8 \bullet \bullet, 9 \bullet, 10^{\bullet}, 11\right]$} \\
\hline SMPD3 & SMPD3 & No & Normal & Unknown & $\begin{array}{l}\text { Reduced SPARC level; } \\
\text { reduced mineralization; } \\
\text { excessive bone resorption }\end{array}$ & {$[58-60]$} \\
\hline
\end{tabular}

substrate is the triple helical domain of intact procollagen trimers in the ER $[32,33]$. Release of collagen from HSP47 takes place in the cis-Golgi or ER-Golgi intermediate compartment and probably is triggered by the lower $\mathrm{pH}$ [34, 35]. The missense mutation in SERPINH1 leads to slightly delayed overall transit time from the ER to the extracellular space due to accumulation in the Golgi [30•]. It points to a possibility that the p.Leu78Pro mutation affects the pH-dependent release of HSP47 in the Golgi and retards collagen secretion, whereas the absence of Hsp47 in mice leads to ER-retention and stress.

A mutation in Dachshunds that also converted a leucine residue to a proline residue (p.Leu326Pro), but near the carboxy-terminal end of HSP47, resulted in a viable yet severe OI phenotype [29]. Again, the mutation probably does not represent a complete null allele but has some residual activity, which results in live-born dogs with OI instead of the embryonic lethality seen in Serpinh1 knockout mice.

Both OI missense mutations occur in the hydrophobic core of HSP47, distant from the collagen binding site [36••]. These mutations most likely severely affect the overall structure, stability and functionality of HSP47.

\section{FKBP65 and LH2}

Two mutations have been reported in FKBP10 (MIM 607063 ) in patients with moderately severe OI and recessive disease transmission [37•]. FKBP10 codes for FKBP65, which is a protein with known type I procollagen chaperone function [38]. Investigation of the FKBP65 mutations in dermal fibroblasts from affected individuals revealed normal 3-hydroxylation of proline 986 but delayed secretion of type I procollagen [37•]. Mutations in FKBP65 have also been described in patients with Bruck syndrome type I [39] and Kuskokwim syndrome [40]. Bruck syndrome type 2 is associated with mutations in PLOD2 (lysyl hydroxylase 2, LH2). It has recently been shown that mutations in FKBP65 lead to a decrease in hydroxylysine residues in the telopeptides of type I collagen in bone [41•]. These hydroxylysines are involved in crosslinking of type I collagen, and LH2 is the enzyme catalyzing this modification. The activity of LH2 seems to be dependent on the presence of FKBP65, in a similar manner that the activity of LH1 seems to require CypB (26).

\section{BMP-1 (mTld)}

The major known function of bone morphogenic protein 1 (BMP-1) is the cleavage of the C-terminal propeptides of procollagen I, II and III. The other function that might contribute to the OI phenotype is the proteolytic activation of lysyl oxidase. Lysyl oxidase catalyzes the posttranslational formation of aldehydes from lysine and hydoxylysine residues in collagen precursors. These highly reactive aldehydes spontaneously form cross-links, which are essential for stabilization of collagen fibrils.

Two types of mutations causing OI were identified in $B M P 1$. One mutation is located within the BMP-1 signal peptide and leads to impaired secretion and an alteration in posttranslational modification [42•]; the other causes an alteration in the protease domain of BMP-1. For both types, concomitant abnormal procollagen I C-propeptide 
processing was observed. However, the following differences were discovered: the signal peptide mutation was accompanied by an increase in bone mineral density, whereas the catalytic domain mutation presented a decrease. No rational explanation exists for this discrepancy at the moment.

An interesting COL1A1 mutation affecting the BMP-1 C-propeptide cleavage site was recently published [43]. The patients presented an increased-mineralization OI phenotype very similar to the signal peptide mutation in BMP-1.

\section{PEDF (Serpin F1)}

Pigment epithelium-derived factor (PEDF) is an ubiquitously expressed and secreted glycoprotein of the serpin superfamily, which is primarily known for its neurotrophic and antiangiogenic properties [44]. Multiple mutations were identified in the coding regions of the SERPINF1 gene that lead to OI $[45 \cdot, 46 \bullet, 47]$. An in-frame duplication in SERPINF1 was reported to be responsible for the OI phenotype in a patient who has the concurrent phenotype of two rare recessive diseases, cystinosis (caused by mutation in the CTNS gene) and OI [48]. In all reported cases so far, synthesis, folding, posttranslational modification and secretion of type I collagen seem to be normal, but bone mineral density is severely reduced. Serum levels of PEDF correlate with the OI caused by mutation in the SERPINF1 gene and can be used for diagnostics [49].

Pedf null mice revealed reduced trabecular bone volume and the accumulation of unmineralized bone matrix. Fourier transformed infrared microscopy (FTIR) indicated an increased mineral:protein matrix ratio in mutant bones, which were more brittle than in controls. In vitro, osteoblasts from Pedf null mice exhibited enhanced mineral deposition as assessed by alizarin red staining and an increased mineral:protein matrix ratio determined by FTIR analysis of calcified nodules [50 ${ }^{\bullet}$.

PEDF was detected in osteoblasts, chondrocytes and, to a lesser extent, osteoclasts, allocated in areas of active bone remodeling [51]. Osteoblasts and osteoclasts express PEDF, VEGF-A isoforms and VEGF receptors, possible mediators of angiogenesis and matrix remodeling in the bone [52]. Type I collagen directly binds secreted PEDF [53] and restrains osteoclast precursor cell differentiation and hence bone resorption [54]. Decrease or loss of PEDF disturbs the balance between osteoblasts and osteoclasts, which leads to excessive bone resorption and development of OI.

\section{TRICB (TMEM38B)}

Trimeric intracellular cation channel type B (TRICB) protein is encoded by transmembrane protein $38 \mathrm{~B}$ gene
(TMEM38B). It forms a multi-pass membrane cation channel that maintains rapid calcium release from intracellular stores [55]. Two reports of the same mutation in TMEM38B causing a recessive form of OI were published last year. The homozygous deletion mutation of exon 4 of TMEM38B in Saudi Arabian [56 ${ }^{\bullet}$ or Israeli Bedouin [57•] consanguineous families. The mutation results in translation of a truncated protein and a four-fold reduction of mRNA levels. The molecular mechanism leading to OI remains unknown. Aberrant function of TRICB might detrimentally affect calcium homeostasis in cell signaling pathways and/or in bone mineralization.

\section{SMPD3 (nSMase2)}

In 1981, a severe form of recessive OI (fragilitas ossium, fro) was discovered in a random-bred stock of mice that could not be attributed to a collagen defect [58]. Defects of type I or V collagen could not be detected from the electrophoretic patterns of $\alpha$ chains and cyanogen bromide-derived peptides [59]. Experiments with cultures of tissue-derived dermal fibroblasts demonstrated no abnormalities in the total collagen synthesis and secretion. A $30 \%$ reduction in bone SPARC (osteonectin) was detected at the protein level, and a $50 \%$ decrease in the mRNA level was found in the cultured fibroblasts. Significantly reduced mineral phase was observed in bones and teeth $[59,60]$. In 2005, a deletion in Smpd3 was identified as the causative mutation in fro mice [60]. Smpd3 encodes sphingomyelin phosphodiesterase 3 (a.k.a. neutral sphingomyelinase 2), which is a Golgi- and cell-membrane associated enzyme that hydrolyzes sphingomyelin into ceramide and phosphocholine. Ceramide is a substrate for ceramidase that produces sphingosine. In turn, sphingosine is modified by a specific kinase and converted into sphingosine 1-phosphate, which has a mitogenic activity on osteoblasts [61]. Neutral sphingomyelinases are ubiquitously expressed enzymes with elevated expression in the brain and in the embryonic growth plate of bone. In fro mice, the activity of the neutral sphingomyelinases from brain extracts was severely deficient ( $\sim 12 \%$ of the control); this residual activity probably resulted from the other neutral sphingomyelinase, Smpd2 [60]. Sphingomyelinase, ceramide and sphingosine 1-phosphate are inhibitory factors of bone resorption [62]. Impaired function of SMPD3 and a defective ceramide pathway could affect bone development and remodeling, leading to excessive bone resorption [60]. The detailed relationship between impaired function of SMPD3 and defective mineralized tissue is not yet fully understood.

\section{Osterix (SP7, OSX)}

$S P 7$ encodes an osteoblast-specific transcription factor that is indispensable for bone formation. $S p 7$ null mice are 
deficient in osteoblast differentiation and have reduced expression of osteoblast markers, including Col1a1, bone sialoprotein and osteocalcin [63]. In an Egyptian child, a c.1052delA mutation was found responsible for recessive OI [64•]. The clinical manifestations include recurrent fractures, mild bone deformities and delayed tooth eruption, but normal hearing and white sclera. The mutation introduces a premature stop codon within the final exon of the gene. The mutant mRNA transcript is predicted to escape the nonsense-mediated mRNA decay machinery [64-]. A truncated Osterix protein lacks the last 81 amino acids, including the third Zn-finger domain, and carries instead 18 new residues. Its DNA-binding properties are expected to be altered, and, consequently, the transcriptional regulation should be impaired. The effect of the SP7 mutation on type I collagen production in patient cells was not analyzed because of the unavailability of additional biological material from the patient [64•].

\section{Wnt1}

A large number of recessive mutations in WNT1 leading to OI were recently reported $[8 \bullet \bullet, 9 \bullet, 10 \bullet, 11]$. The WNT signaling pathway is not only involved in developmental processes, but also in bone homeostasis. Loss-of-function mutations in LRP5, encoding the WNT co-receptor for the canonical WNT- $\beta$-catenin pathway, lead to low bone mass, whereas gain-of-function mutations in LRP5 lead to high bone mass. These high bone mass-causing mutations are linked to a decrease in binding to sclerostin [65]. The precise role of WNTI in the WNT- $\beta$-catenin pathway is still elusive, but it is interesting that Osterix is a downstream target of $\beta$-catenin-activated transcription factor TCF/LEF.

\section{Conclusions}

Human genome sequencing and rapid development of cheap and efficient sequencing techniques has allowed mapping of new genes and new mutations responsible for multiple inherited disorders at an unprecedented rate. Recent findings of mutations leading to OI in genes not encoding $\alpha 1$ and $\alpha 2$ chains of type I collagen significantly broadened the diagnostic repertoire for medical geneticists, which can now be used to counsel patients and families with OI. It is possible that the repertoire is still incomplete and more discoveries are to come. Unfortunately, detailed studies of molecular and cellular mechanisms underlying these new mutations are significantly lagging behind. Several OI-related genes encoding TMEM38B, IFITM5, SERPINF1 and SMPD3 are of unknown relation to disturbed bone tissue. Our understanding of the roles of
FKBP65 and HSP47 in collagen folding remains elusive. Functions of the $\mathrm{P} 3 \mathrm{H} 1 \cdot \mathrm{CRTAP} \cdot \mathrm{CypB}$ complex are still not fully explored. There are "black boxes" hiding roles of Wnt1 signaling and collagen transcription regulated by Osterix. OI mutations are pieces of an exciting "puzzle" called "bone formation, structure and function" in a very broad meaning that includes multiple steps of biosynthesis of the collagen matrix and bone mineralization, as well as a sophisticated signaling network within the matrix and cells. By solving this puzzle we will benefit by uncovering new targets for OI treatment.

Acknowledgments Hans Peter Bächinger is supported by grants from the Shriners Hospitals for Children.

\section{Compliance with Ethics Guidelines}

Conflict of Interest All authors declare no conflicts of interest.

Human and Animal Rights and Informed Consent This article does not contain any studies with human or animal subjects performed by any of the authors.

\section{References}

Papers of particular interest, published recently, have been highlighted as:

- Of importance;

•• Of major importance

1. Glorieux FH. Osteogenesis imperfecta. Best Pract Res Clin Rheumatol. 2008;22:85-100.

2. Jepsen KJ, Schaffler MB, Kuhn JL, Goulet RW, Bonadio J, Goldstein SA. Type I collagen mutation alters the strength and fatigue behavior of Mov13 cortical tissue. J Biomech. 1997;30:1141-7.

3. Pokidysheva E, Zientek KD, Ishikawa Y, Mizuno K, Vranka JA, Montgomery NT, Keene DR, Kawaguchi T, Okuyama K, Bachinger HP. Posttranslational modifications in Type I collagen from different tissues extracted from wild type and prolyl 3-hydroxylase 1 null mice. J Biol Chem. 2013;288:24742-52. This study shows the variability in 3-hydroxylation modification of collagen among skin, tendon and bone, as well as change in the expression profile of 3-hydroxylases.

4. Lisse TS, Thiele F, Fuchs H, Hans W, Przemeck GK, Abe K, Rathkolb B, Quintanilla-Martinez L, Hoelzlwimmer G, Helfrich M, Wolf E, Ralston SH, Hrabe de Angelis M. ER stress-mediated apoptosis in a new mouse model of osteogenesis imperfecta. PLoS Genet. 2008;4:e7.

5. • Cho TJ, Lee KE, Lee SK, Song SJ, Kim KJ, Jeon D, Lee G, Kim HN, Lee HR, Eom HH, Lee ZH, Kim OH, Park WY, Park SS, Ikegawa S, Yoo WJ, Choi IH, Kim JW. A single recurrent mutation in the 5'-UTR of IFITM5 causes osteogenesis imperfecta type V. Am J Hum Genet. 2012;91:343-8. In this study, a dominant mutation leading to OI was discovered in a gene encoding interferon-induced transmembrane protein 5, a new player in bone development.

6. - Semler O, Garbes L, Keupp K, Swan D, Zimmermann K, Becker J, Iden S, Wirth B, Eysel P, Koerber F, Schoenau E, Bohlander SK, Wollnik B, Netzer C. A mutation in the $5^{\prime}$-UTR of 
IFITM5 creates an in-frame start codon and causes autosomaldominant osteogenesis imperfecta type $\mathrm{V}$ with hyperplastic callus. Am J Hum Genet. 2012;91:349-57. An independent discovery of a mutation in the $5^{\prime}$-UTR of IFITM5 suggesting an addition of five amino acids to the $N$ terminus, which alters IFITM5 function in individuals with $O I$.

7. Faqeih E, Shaheen R, Alkuraya FS. WNT1 mutation with recessive osteogenesis imperfecta and profound neurological phenotype. J Med Genet. 2013;50:491-2.

8. •- Laine CM, Joeng KS, Campeau PM, Kiviranta R, Tarkkonen K, Grover M, Lu JT, Pekkinen M, Wessman M, Heino TJ, Nieminen-Pihala V, Aronen M, Laine T, Kroger H, Cole WG, Lehesjoki AE, Nevarez L, Krakow D, Curry CJ, Cohn DH, Gibbs RA, Lee BH, Makitie O. WNT1 mutations in early-onset osteoporosis and osteogenesis imperfecta. $\mathrm{N}$ Engl $\mathrm{J}$ Med. 2013;368:1809-16. This study opened a new era of studying OI mechanisms, as it identified a crucial role of canonical WNT signaling in bone development.

9. - Pyott SM, Tran TT, Leistritz DF, Pepin MG, Mendelsohn NJ, Temme RT, Fernandez BA, Elsayed SM, Elsobky E, Verma I, Nair S, Turner EH, Smith JD, Jarvik GP, Byers PH. WNT1 mutations in families affected by moderately severe and progressive recessive osteogenesis imperfecta. Am J Hum Genet. 2013;92:590-7. An independent report of OI mutation in WNT1.

10. - Keupp K, Beleggia F, Kayserili H, Barnes AM, Steiner M, Semler O, Fischer B, Yigit G, Janda CY, Becker J, Breer S, Altunoglu U, Grunhagen J, Krawitz P, Hecht J, Schinke T, Makareeva E, Lausch E, Cankaya T, Caparros-Martin JA, Lapunzina P, Temtamy S, Aglan M, Zabel B, Eysel P, Koerber F, Leikin S, Garcia KC, Netzer C, Schonau E, Ruiz-Perez VL, Mundlos S, Amling M, Kornak U, Marini J, Wollnik B. Mutations in WNT1 cause different forms of bone fragility. Am J Hum Genet. 2013;92:565-74. Another independent report of OI mutation in WNT1.

11. Fahiminiya S, Majewski J, Mort J, Moffatt P, Glorieux FH, Rauch F. Mutations in WNT1 are a cause of osteogenesis imperfecta. J Med Genet. 2013;50:345-8.

12. Morello R, Bertin TK, Chen Y, Hicks J, Tonachini L, Monticone M, Castagnola P, Rauch F, Glorieux FH, Vranka J, Bachinger HP, Pace JM, Schwarze U, Byers PH, Weis M, Fernandes RJ, Eyre DR, Yao Z, Boyce BF, Lee B. CRTAP is required for prolyl 3-hydroxylation and mutations cause recessive osteogenesis imperfecta. Cell. 2006;127:291-304.

13. Vranka JA, Sakai LY, Bachinger HP. Prolyl 3-hydroxylase 1, enzyme characterization and identification of a novel family of enzymes. J Biol Chem. 2004;279:23615-21.

14. - Vranka JA, Pokidysheva E, Hayashi L, Zientek K, Mizuno K, Ishikawa Y, Maddox K, Tufa S, Keene DR, Klein R, Bachinger HP. Prolyl 3-hydroxylase 1 null mice display abnormalities in fibrillar collagen-rich tissues such as tendons, skin, and bones. J Biol Chem. 2010;285:17253-62. In this study, the actual rate of collagen folding was investigated and shown to be delayed in P3H1 null mice.

15. Marini JC, Cabral WA, Barnes AM. Null mutations in LEPRE1 and CRTAP cause severe recessive osteogenesis imperfecta. Cell Tissue Res. 2010;339:59-70.

16. Van Dijk FS, Nesbitt IM, Nikkels PG, Dalton A, Bongers EM, van de Kamp JM, Hilhorst-Hofstee Y, Den Hollander NS, Lachmeijer AM, Marcelis CL, Tan-Sindhunata GM, van Rijn RR, Meijers-Heijboer H, Cobben JM, Pals G. CRTAP mutations in lethal and severe osteogenesis imperfecta: the importance of combining biochemical and molecular genetic analysis. Eur J Hum Genet. 2009;17:1560-9.

17. van Dijk FS, Nesbitt IM, Zwikstra EH, Nikkels PG, Piersma SR, Fratantoni SA, Jimenez CR, Huizer M, Morsman AC, Cobben JM, van Roij MH, Elting MW, Verbeke JI, Wijnaendts LC, Shaw
NJ, Hogler W, McKeown C, Sistermans EA, Dalton A, MeijersHeijboer H, Pals G. PPIB mutations cause severe osteogenesis imperfecta. Am J Hum Genet. 2009;85:521-7.

18. Baldridge D, Schwarze U, Morello R, Lennington J, Bertin TK, Pace JM, Pepin MG, Weis M, Eyre DR, Walsh J, Lambert D, Green A, Robinson H, Michelson M, Houge G, Lindman C, Martin J, Ward J, Lemyre E, Mitchell JJ, Krakow D, Rimoin DL, Cohn DH, Byers PH, Lee B. CRTAP and LEPRE1 mutations in recessive osteogenesis imperfecta. Hum Mutat. 2008;29: $1435-42$.

19. Cabral WA, Chang W, Barnes AM, Weis M, Scott MA, Leikin S, Makareeva E, Kuznetsova NV, Rosenbaum KN, Tifft CJ, Bulas DI, Kozma C, Smith PA, Eyre DR, Marini JC. Prolyl 3-hydroxylase 1 deficiency causes a recessive metabolic bone disorder resembling lethal/severe osteogenesis imperfecta. Nat Genet. 2007;39:359-65.

20. Barnes AM, Chang W, Morello R, Cabral WA, Weis M, Eyre DR, Leikin S, Makareeva E, Kuznetsova N, Uveges TE, Ashok A, Flor AW, Mulvihill JJ, Wilson PL, Sundaram UT, Lee B, Marini JC. Deficiency of cartilage-associated protein in recessive lethal osteogenesis imperfecta. N Engl J Med. 2006;355:2757-64.

21. Choi JW, Sutor SL, Lindquist L, Evans GL, Madden BJ, Bergen HR 3rd, Hefferan TE, Yaszemski MJ, Bram RJ. Severe osteogenesis imperfecta in cyclophilin B-deficient mice. PLoS Genet. 2009;5:e1000750.

22. Barnes AM, Carter EM, Cabral WA, Weis M, Chang W, Makareeva E, Leikin S, Rotimi CN, Eyre DR, Raggio CL, Marini JC. Lack of cyclophilin B in osteogenesis imperfecta with normal collagen folding. N Engl J Med. 2010;362:521-8.

23. - Takagi M, Ishii T, Barnes AM, Weis M, Amano N, Tanaka M, Fukuzawa R, Nishimura G, Eyre DR, Marini JC, Hasegawa T. A Novel mutation in LEPRE1 that eliminates only the KDEL ERretrieval sequence causes non-lethal osteogenesis imperfecta. PLoS One. 2012;7:e36809. This study highlights the role of collagen overmodification in developing OI, as the mutation in P3H1 does not significantly affect 3-hydroxylation of Pro 986.

24. Constantinou CD, Nielsen KB, Prockop DJ. A lethal variant of osteogenesis imperfecta has a single base mutation that substitutes cysteine for glycine 904 of the alpha 1(I) chain of type I procollagen. The asymptomatic mother has an unidentified mutation producing an overmodified and unstable type I procollagen. J Clin Invest. 1989;83:574-84.

25. Steinmann B, Rao VH, Vogel A, Bruckner P, Gitzelmann R, Byers $\mathrm{PH}$. Cysteine in the triple-helical domain of one allelic product of the alpha 1(I) gene of type I collagen produces a lethal form of osteogenesis imperfecta. J Biol Chem. 1984;259:11129-38.

26. Ishikawa Y, Wirz J, Vranka JA, Nagata K, Bachinger HP. Biochemical characterization of the prolyl 3-hydroxylase 1. cartilage-associated protein.cyclophilin B complex. J Biol Chem. 2009;284:17641-7.

27. • Ishikawa Y, Vranka JA, Boudko SP, Pokidysheva E, Mizuno K, Zientek K, Keene DR, Rashmir-Raven AM, Nagata K, Winand NJ, Bachinger HP. The mutation in cyclophilin B that causes hyperelastosis cutis in the American Quarter Horse does not affect peptidyl-prolyl cis-trans isomerase activity, but shows altered cyclophilin B-protein interactions and affects collagen folding. J Biol Chem. 2012;287:22253-65. This study characterizes a mutation in PPIB that does not lead to OI, but suggests an alternative role of CypB in regulating lysysl hydroxylation of collagen.

28. - Pokidysheva E, Mizuno K, Bachinger HP. The collagen folding machinery: biosynthesis and posttranslational modifications of collagen. In: Shapiro J, Buyers P, Glorieux F, Sponsellor P, editors. Osteogenesis imperfecta, a translational approach to brittle bone disease. Edinburgh: Elsevier; 2013. Chapter 6. This book chapter gives a detailed description of collagen synthesis and modifications. 
29. Drogemuller C, Becker D, Brunner A, Haase B, Kircher P, Seeliger F, Fehr M, Baumann U, Lindblad-Toh K, Leeb T. A missense mutation in the SERPINH1 gene in Dachshunds with osteogenesis imperfecta. PLoS Genet. 2009;5:e1000579.

30. - Christiansen HE, Schwarze U, Pyott SM, AlSwaid A, Al Balwi M, Alrasheed S, Pepin MG, Weis MA, Eyre DR, Byers PH. Homozygosity for a missense mutation in SERPINH1, which encodes the collagen chaperone protein HSP47, results in severe recessive osteogenesis imperfecta. Am J Hum Genet. 2010;86:389-98. This study represents an OI mutation in SERPINH1 with an unexpected delay of collagen secretion in the Golgi, which might shed light on a mechanism of HSP47 release from collagen.

31. Nagai N, Hosokawa M, Itohara S, Adachi E, Matsushita T, Hosokawa N, Nagata K. Embryonic lethality of molecular chaperone hsp47 knockout mice is associated with defects in collagen biosynthesis. J Cell Biol. 2000;150:1499-506.

32. Koide T, Nishikawa Y, Asada S, Yamazaki CM, Takahara Y, Homma DL, Otaka A, Ohtani K, Wakamiya N, Nagata K, Kitagawa K. Specific recognition of the collagen triple helix by chaperone HSP47. II. The HSP47-binding structural motif in collagens and related proteins. J Biol Chem. 2006;281:11177-85.

33. Tasab M, Batten MR, Bulleid NJ. Hsp47: a molecular chaperone that interacts with and stabilizes correctly-folded procollagen. EMBO J. 2000;19:2204-11.

34. Saga S, Nagata K, Chen WT, Yamada KM. pH-dependent function, purification, and intracellular location of a major collagen-binding glycoprotein. J Cell Biol. 1987;105:517-27.

35. Thomson CA, Ananthanarayanan VS. Structure-function studies on hsp47: pH-dependent inhibition of collagen fibril formation in vitro. Biochem J. 2000;349(Pt 3):877-83.

36. •• Widmer C, Gebauer JM, Brunstein E, Rosenbaum S, Zaucke F, Drogemuller C, Leeb T, Baumann U. Molecular basis for the action of the collagen-specific chaperone Hsp47/SERPINH1 and its structure-specific client recognition. Proc Natl Acad Sci USA. 2012;109:13243-7. This study reports for the first time the detailed atomic structure of an HSP47 and collagen complex and provides a mechanism for collagen stabilization in the ER.

37. - Alanay Y, Avaygan H, Camacho N, Utine GE, Boduroglu K, Aktas D, Alikasifoglu M, Tuncbilek E, Orhan D, Bakar FT, Zabel B, Superti-Furga A, Bruckner-Tuderman L, Curry CJ, Pyott S, Byers PH, Eyre DR, Baldridge D, Lee B, Merrill AE, Davis EC, Cohn DH, Akarsu N, Krakow D. Mutations in the gene encoding the RER protein FKBP65 cause autosomal-recessive osteogenesis imperfecta. Am J Hum Genet. 2010;86:551-9. This study established the link between OI and mutations in a gene encoding FKBP65, a chaperone for procollagen folding.

38. Ishikawa Y, Vranka J, Wirz J, Nagata K, Bachinger HP. The rough endoplasmic reticulum-resident FK506-binding protein FKBP65 is a molecular chaperone that interacts with collagens. J Biol Chem. 2008;283:31584-90.

39. Kelley BP, Malfait F, Bonafe L, Baldridge D, Homan E, Symoens S, Willaert A, Elcioglu N, Van Maldergem L, VerellenDumoulin C, Gillerot Y, Napierala D, Krakow D, Beighton P, Superti-Furga A, De Paepe A, Lee B. Mutations in FKBP10 cause recessive osteogenesis imperfecta and Bruck syndrome. $\mathrm{J}$ Bone Miner Res. 2011;26:666-72.

40. Barnes AM, Duncan G, Weis M, Paton W, Cabral WA, Mertz EL, Makareeva E, Gambello MJ, Lacbawan FL, Leikin S, Fertala A, Eyre DR, Bale SJ, Marini JC. Kuskokwim syndrome, a recessive congenital contracture disorder, extends the phenotype of FKBP10 mutations. Hum Mutat. 2013; doi:10.1002/humu. 22362.

41. - Schwarze U, Cundy T, Pyott SM, Christiansen HE, Hegde MR, Bank RA, Pals G, Ankala A, Conneely K, Seaver L, Yandow SM, Raney E, Babovic-Vuksanovic D, Stoler J, Ben-Neriah Z, Segel
R, Lieberman S, Siderius L, Al-Aqeel A, Hannibal M, Hudgins L, McPherson E, Clemens M, Sussman MD, Steiner RD, Mahan J, Smith R, Anyane-Yeboa K, Wynn J, Chong K, Uster T, Aftimos S, Sutton VR, Davis EC, Kim LS, Weis MA, Eyre D, Byers PH. Mutations in FKBP10, which result in Bruck syndrome and recessive forms of osteogenesis imperfecta, inhibit the hydroxylation of telopeptide lysines in bone collagen. Hum Mol Genet. 2013;22:1-17. This study demonstrates the role of FKBP65 (FKBP10) in the hydroxylation of telopeptide lysines in collagen and suggests coordination of function between FKBP65 and lysyl hydroxylase- 2 .

42. • Asharani PV, Keupp K, Semler O, Wang W, Li Y, Thiele H, Yigit G, Pohl E, Becker J, Frommolt P, Sonntag C, Altmuller J, Zimmermann K, Greenspan DS, Akarsu NA, Netzer C, Schonau E, Wirth R, Hammerschmidt M, Nurnberg P, Wollnik B, Carney TJ. Attenuated BMP1 function compromises osteogenesis, leading to bone fragility in humans and zebrafish. Am J Hum Genet. 2012;90: 661-74. This study reports an OI mutation in the collagen C-propeptide cleavage enzyme that is critical for initiating fibrillogenesis.

43. Lindahl K, Barnes AM, Fratzl-Zelman N, Whyte MP, Hefferan TE, Makareeva E, Brusel M, Yaszemski MJ, Rubin CJ, Kindmark A, Roschger P, Klaushofer K, McAlister WH, Mumm S, Leikin S, Kessler E, Boskey AL, Ljunggren O, Marini JC. COL1 C-propeptide cleavage site mutations cause high bone mass osteogenesis imperfecta. Hum Mutat. 2011;32:598-609.

44. Craword SE, Fitchev P, Veliceasa D, Volpert OV. The many facets of PEDF in drug discovery and disease: a diamond in the rough or split personality disorder? Expert Opin Drug Discov. 2013;8:769-92.

45. - Becker J, Semler O, Gilissen C, Li Y, Bolz HJ, Giunta C, Bergmann C, Rohrbach M, Koerber F, Zimmermann K, de Vries P, Wirth B, Schoenau E, Wollnik B, Veltman JA, Hoischen A, Netzer C. Exome sequencing identifies truncating mutations in human SERPINF1 in autosomal-recessive osteogenesis imperfecta. Am J Hum Genet. 2011;88:362-71. In this study OI mutations in SERPINF1 were identified for the first time.

46. • Homan EP, Rauch F, Grafe I, Lietman C, Doll JA, Dawson B, Bertin T, Napierala D, Morello R, Gibbs R, White L, Miki R, Cohn DH, Crawford S, Travers R, Glorieux FH, Lee B. Mutations in SERPINF1 cause osteogenesis imperfecta type VI. J Bone Miner Res. 2011;26:2798-803. The second independent report of the OI mutations in SERPINF1.

47. Venturi G, Gandini A, Monti E, Dalle Carbonare L, Corradi M, Vincenzi M, Valenti MT, Valli M, Pelilli E, Boner A, Mottes M, Antoniazzi F. Lack of expression of SERPINF1, the gene coding for pigment epithelium-derived factor, causes progressively deforming osteogenesis imperfecta with normal type I collagen. J Bone Miner Res. 2012;27:723-8.

48. Tucker T, Nelson T, Sirrs S, Roughley P, Glorieux FH, Moffatt P, Schlade-Bartusiak K, Brown L, Rauch F. A co-occurrence of osteogenesis imperfecta type VI and cystinosis. Am J Med Genet A. 2012;158A:1422-6.

49. Rauch F, Husseini A, Roughley P, Glorieux FH, Moffatt P. Lack of circulating pigment epithelium-derived factor is a marker of osteogenesis imperfecta type VI. J Clin Endocrinol Metab. 2012;97:E1550-6.

50. • Bogan R, Riddle RC, Li Z, Kumar S, Nandal A, Faugere MC, Boskey A, Crawford SE, Clemens TL. A mouse model for human osteogenesis imperfecta type VI. J Bone Miner Res. 2013;28:1531-6. This study presents a new mouse model for OI that might significantly advance our understanding of the role of collagen in depositing growth factors and stimulate development of new drugs against low mineral density.

51. Quan GM, Ojaimi J, Li Y, Kartsogiannis V, Zhou H, Choong PF. Localization of pigment epithelium-derived factor in growing mouse bone. Calcif Tissue Int. 2005;76:146-53. 
52. Tombran-Tink J, Barnstable CJ. Osteoblasts and osteoclasts express PEDF, VEGF-A isoforms, and VEGF receptors: possible mediators of angiogenesis and matrix remodeling in the bone. Biochem Biophys Res Commun. 2004;316:573-9.

53. Meyer C, Notari L, Becerra SP. Mapping the type I collagenbinding site on pigment epithelium-derived factor. Implications for its antiangiogenic activity. J Biol Chem. 2002;277:45400-7.

54. Akiyama T, Dass CR, Shinoda Y, Kawano H, Tanaka S, Choong PF. PEDF regulates osteoclasts via osteoprotegerin and RANKL. Biochem Biophys Res Commun. 2010;391:789-94.

55. Yamazaki D, Komazaki S, Nakanishi H, Mishima A, Nishi M, Yazawa M, Yamazaki T, Taguchi R, Takeshima H. Essential role of the TRIC-B channel in $\mathrm{Ca}^{2+}$ handling of alveolar epithelial cells and in perinatal lung maturation. Development. 2009;136:2355-61.

56. - Shaheen R, Alazami AM, Alshammari MJ, Faqeih E, Alhashmi N, Mousa N, Alsinani A, Ansari S, Alzahrani F, Al-Owain M, Alzayed ZS, Alkuraya FS. Study of autosomal recessive osteogenesis imperfecta in Arabia reveals a novel locus defined by TMEM38B mutation. J Med Genet. 2012;49:630-5. This is one of two independent studies identifying a new OI gene encoding a trans-membrane protein involved in calcium homeostasis.

57. - Volodarsky M, Markus B, Cohen I, Staretz-Chacham O, Flusser $\mathrm{H}$, Landau D, Shelef I, Langer Y, Birk OS. A deletion mutation in TMEM38B associated with autosomal recessive osteogenesis imperfecta. Hum Mutat. 2013;34:582-6. This is one of two independent studies that identifies a new OI gene encoding a trans-membrane protein involved in calcium homeostasis.

58. Guenet JL, Stanescu R, Maroteaux P, Stanescu V. Fragilitas ossium: a new autosomal recessive mutation in the mouse. J Hered. 1981;72:440-1.

59. Muriel MP, Bonaventure J, Stanescu R, Maroteaux P, Guenet JL, Stanescu V. Morphological and biochemical studies of a mouse mutant (fro/fro) with bone fragility. Bone. 1991;12:241-8.

60. Aubin I, Adams CP, Opsahl S, Septier D, Bishop CE, Auge N, Salvayre R, Negre-Salvayre A, Goldberg M, Guenet JL, Poirier C. A deletion in the gene encoding sphingomyelin phosphodiesterase $3(\mathrm{Smpd} 3)$ results in osteogenesis and dentinogenesis imperfecta in the mouse. Nat Genet. 2005;37:803-5.

61. Grey A, Xu X, Hill B, Watson M, Callon K, Reid IR, Cornish J. Osteoblastic cells express phospholipid receptors and phosphatases and proliferate in response to sphingosine-1-phosphate. Calcif Tissue Int. 2004;74:542-50.

62. Takeda H, Ozaki K, Yasuda H, Ishida M, Kitano S, Hanazawa S. Sphingomyelinase and ceramide inhibit formation of F-actin ring in and bone resorption by rabbit mature osteoclasts. FEBS Lett. 1998;422:255-8.

63. Nakashima K, Zhou X, Kunkel G, Zhang Z, Deng JM, Behringer $\mathrm{RR}$, de Crombrugghe $\mathrm{B}$. The novel zinc finger-containing transcription factor osterix is required for osteoblast differentiation and bone formation. Cell. 2002;108:17-29.

64. - Lapunzina P, Aglan M, Temtamy S, Caparros-Martin JA, Valencia M, Leton R, Martinez-Glez V, Elhossini R, Amr K, Vilaboa N, Ruiz-Perez VL. Identification of a frameshift mutation in Osterix in a patient with recessive osteogenesis imperfecta. Am J Hum Genet. 2010;87:110-4. This is a first demonstration that a transcription factor can be responsible for OI.

65. Baron R, Kneissel M. WNT signaling in bone homeostasis and disease: from human mutations to treatments. Nat Med. 2013; 19:179-92.

66. van Dijk FS, Nikkels PG, den Hollander NS, Nesbitt IM, van Rijn RR, Cobben JM, Pals G. Lethal/severe osteogenesis imperfecta in a large family: a novel homozygous LEPRE1 mutation and bone histological findings. Pediatr Dev Pathol. 2012;14:228-34.
67. Zhang ZL, Zhang H, Ke YH, Yue H, Xiao WJ, Yu JB, Gu JM, Hu WW, Wang C, He JW, Fu WZ. The identification of novel mutations in COL1A1, COL1A2, and LEPRE1 genes in Chinese patients with osteogenesis imperfecta. J Bone Miner Metab. 2012;30:69-77.

68. Marini JC, Cabral WA, Barnes AM, Chang W. Components of the collagen prolyl 3-hydroxylation complex are crucial for normal bone development. Cell Cycle. 2007;6:1675-81.

69. Valli M, Barnes A, Gallanti A, Cabral W, Viglio S, Weis M, Makareeva E, Eyre D, Leikin S, Antoniazzi F, Marini J, Mottes M. Deficiency of CRTAP in non-lethal recessive osteogenesis imperfecta reduces collagen deposition into matrix. Clin Genet. 2012;82:453-9.

70. Pyott SM, Schwarze U, Christiansen HE, Pepin MG, Leistritz DF, Dineen R, Harris C, Burton BK, Angle B, Kim K, Sussman MD, Weis M, Eyre DR, Russell DW, McCarthy KJ, Steiner RD, Byers PH. Mutations in PPIB (cyclophilin B) delay type I procollagen chain association and result in perinatal lethal to moderate osteogenesis imperfecta phenotypes. Hum Mol Genet. 2011;20:1595-609.

71. Schwarze U, Pyott S, Russell DW, Sussman MD, Harris C, Byers $\mathrm{PH}$. Mutations in PPIB which encodes a prolyl cis-trans isomerase (cyclophilin B) in recessive forms of osteogenesis imperfecta (OI). 59th Annual Meeting of the American Society of Human Genetics. October 20-24. 2009;79.

72. van Dijk FS, Cobben JM, Pals G. Osteogenesis imperfecta, normal collagen folding, and lack of cyclophilin B. N Engl J Med. 2010;362:1940-1 Author reply 1-2.

73. Venturi G, Monti E, Dalle Carbonare L, Corradi M, Gandini A, Valenti MT, Boner A, Antoniazzi F. A novel splicing mutation in FKBP10 causing osteogenesis imperfecta with a possible mineralization defect. Bone. 2012;50:343-9.

74. Barnes AM, Cabral WA, Weis M, Makareeva E, Mertz EL, Leikin S, Eyre D, Trujillo C, Marini JC. Absence of FKBP10 in recessive type XI OI leads to diminished collagen cross-linking and reduced collagen deposition in extracellular matrix. Hum Mutat. 2012;33:1589-98.

75. Shaheen R, Al-Owain M, Faqeih E, Al-Hashmi N, Awaji A, AlZayed Z, Alkuraya FS. Mutations in FKBP10 cause both Bruck syndrome and isolated osteogenesis imperfecta in humans. Am J Med Genet A. 2011;155A:1448-52.

76. Setijowati ED, van Dijk FS, Cobben JM, van Rijn RR, Sistermans EA, Faradz SM, Kawiyana S, Pals G. A novel homozygous 5 bp deletion in FKBP10 causes clinically Bruck syndrome in an Indonesian patient. Eur J Med Genet. 2011;55:17-21.

77. Ha-Vinh R, Alanay Y, Bank RA, Campos-Xavier AB, Zankl A, Superti-Furga A, Bonafe L. Phenotypic and molecular characterization of Bruck syndrome (osteogenesis imperfecta with contractures of the large joints) caused by a recessive mutation in PLOD2. Am J Med Genet A. 2004;131:115-20.

78. Puig-Hervas MT, Temtamy S, Aglan M, Valencia M, MartinezGlez V, Ballesta-Martinez MJ, Lopez-Gonzalez V, Ashour AM, Amr K, Pulido V, Guillen-Navarro E, Lapunzina P, CaparrosMartin JA, Ruiz-Perez VL. Mutations in PLOD2 cause autosomal-recessive connective tissue disorders within the Bruck syndrome-osteogenesis imperfecta phenotypic spectrum. Hum Mutat. 2012;33:1444-9.

79. Martinez-Glez V, Valencia M, Caparros-Martin JA, Aglan M, Temtamy S, Tenorio J, Pulido V, Lindert U, Rohrbach M, Eyre D, Giunta C, Lapunzina P, Ruiz-Perez VL. Identification of a mutation causing deficient BMP1/mTLD proteolytic activity in autosomal recessive osteogenesis imperfecta. Hum Mutat. 2012;33:343-50. 